\title{
South Africa's Debut into Broadcasting \\ Criminal Trials - The Legal Arguments in \\ Televising the Oscar Pistorius Trail
}

\section{AAW James*}

\section{P.E.R}

Pioneer in peer-reviewed, open access online law publications

Author

Amanda James

Affiliation

Advocate of the High Court of South Africa, South Africa

Email amanda5806@zoho.com

Date published

5 December 2017

Editor Prof AA du Plessis

How to cite this article

James AAW "South Africa's Debut into Broadcasting Criminal Trials The Legal Arguments in Televising the Oscar Pistorius Trail" PER / PELJ 2017(20) - DOI

http://dx.doi.org/10.17159/17273781/2017/v20i0a1516

\section{Copyright}

DOI

http://dx.doi.org/10.17159/17273781/2017/v20i0a1516

\begin{abstract}
The televising and/or any other form of broadcasting of judicial hearings and of criminal trials in particular is a controversial topic that has not only provoked debate and been argued about by academics, the media and the public for years, but continues to be argued about with few signs of abatement. Until recently South Africa had largely escaped becoming embroiled in this provocative topic, as the live broadcasting of criminal trials from South African courtrooms did not occur. The situation has changed, though, following the recent live televising of a full criminal trial - namely, the trial of South African Para-Olympic champion Oscar Pistorius. Given that this trial signalled South Africa's debut into the world of the live televising of criminal trial proceedings, the question is asked why exactly South Africa ventured into this contentious legal territory.

It must be emphasised that the intention of this contribution is solely to explore the court's consideration of the constitutional mandates and rights that were contained in both the application and the opposing arguments pertaining to the live broadcast the trial of Oscar Pistorius. This note will not attempt to examine or even approach the far greater question of whether criminal trials should be televised or not, a topic better left to future research.
\end{abstract}

\section{Keywords}

Oscar Pistorius; criminal trial; television broadcasting; constitutional rights; public interest; administration of justice; freedom of the press; fair trial. 


\section{Introduction}

Following the tragic and untimely death of twenty-nine year old model Reeva Steenkamp on the night of the 14th February 2013, her then boyfriend, South African Para-Olympic champion Oscar Pistorius ${ }^{1}$, was charged with her premeditated murder - the initiation of a criminal process that precipitated a media frenzy previously unknown in South Africa and one that launched a new legal era in the country. As was both predictable and inevitable, however, that furore has now receded from the media headlines, creating an opportune time to examine why the trial of Oscar Pistorius was in fact televised. ${ }^{2}$ It was after all the first, and to date the only, fully "live"3 televised criminal trial in South Africa's judicial history. ${ }^{4}$ Not only was it unique as a milestone, but in addition the application to televise and widely broadcast the trial was also judicially decided under consideration of the Constitution of the Republic of South Africa, 1996 (hereafter Constitution), thus setting a precedent for both the public and the media's constitutional rights of technological access to criminal trials in the future.

\section{The application}

The legal process which culminated in the broadcasting of the Pistorius trial had its genesis in an application brought before the Judge President of the Gauteng Division of the High Court. ${ }^{5}$ Unlike countries such as the United States of America, South Africa had historically experienced a lower demand for the televising of criminal trials (or even other judicial hearings), perhaps because commercial television became available in the country only in 1976 and, except for paid services, still today has only a limited number of channels. ${ }^{6}$ Further contributory factors may possibly be the lack of general access by the populace to technological media and/or the lack of

Amanda James. LLB (cum laude), LLM (cum laude), Advocate of the High Court of South Africa. Email: amanda5806@zoho.com.

$S$ v Pistorius 2014 ZAGPPHC 793 (12 September 2014).

$S$ v Pistorius 2014 ZAGPPHC 793 (12 September 2014).

The term "live" is used signify that an event can be watched as it occurs. This is sometimes also referred to as "real-time".

$4 \quad$ At the time of writing, the live televising of the murder trial of van Breda has been halted.

$5 \quad$ Multichoice (Pty) Ltd v National Prosecuting Authority, In Re; S v Pistorius, In Re; Media 24 Ltd v Director of Public Prosecutions North Gauteng 20141 SACR 589 (GP) (hereafter Application case).

6 Primarily SABC 1, 2, 3 \& e-TV. Other major international channels are available via paid subscription. 
a wide-spread sophisticated audience. ${ }^{7}$ Notwithstanding these possible obstacles, the news channels eNCA, MultiChoice and Eyewitness News still submitted motions to court seeking permission to electronically monitor and broadcast the coming Pistorius trial, not only by audio transmission and still photographic means, but also by full live television broadcast. ${ }^{8}$

To support their motion the applicants jointly argued, in the main, that the Constitution guaranteed them the right to freedom of expression. ${ }^{9}$ Supplementing this major contention were their submissions that the television and audio broadcasting of the trial would provide educational benefit to the general public about the workings of South Africa's justice system, that the general public had the right to information, that such proposed coverage was in accordance with the "open justice" principle and, finally, that the trial was a matter of intense public interest. ${ }^{10}$

Pistorius vehemently opposed the application, claiming that any such media coverage would deny him his constitutionally guaranteed right to a fair trial. ${ }^{11}$ The Olympic champion supported his opposition by submitting that the mere knowledge of the presence of audio-visual equipment (especially cameras) would inhibit not only him but would also inhibit his witnesses, particularly when they were called upon to give evidence. In addition, Pistorius further contended that his Counsel could also be inhibited when they were questioning prosecution and defence witnesses and, ${ }^{12}$ most importantly, when they were presenting his defence to a criminal charge which carried the potential for a minimal incarceration of fifteen years. ${ }^{13}$

In reinforcing his opposition to the technological coverage, Pistorius ardently emphasised to the court that live coverage of the trial would necessarily and inescapably provide pending trial witnesses with opportunities to fabricate and/or adapt their own upcoming testimony. This, he maintained, would be made possible simply because witnesses would be able to follow the live

Stats SA 2011 http://www.statssa.gov.za/publications/P03014/P030142011.pdf. The 2011 Census indicated only $25.8 \%$ of households have satellite television while $64.8 \%$ have no access to the internet. Application case para 3 . Various applicants represented both television and the print media and the court considered all the applications together to enable a consolidated order to be issued.

$9 \quad$ Application case para 6.

$10 \quad$ Application case para 4.

$11 \quad$ Application case para 12.

$12 \quad$ Application case para 12.

13 Section 51(2)(a)(i) of the Criminal Law Amendment Act 105 of 1997 prescribes a minimum sentence of fifteen years' incarceration for a first offender found guilty of premeditated murder. 
broadcasts on their own electronic devices and thus would have foreknowledge of what previous witnesses had already testified to during the trial, and/or alternatively, what evidence had already been presented in the courtroom. ${ }^{14} \mathrm{He}$ contended that this factor alone would not only threaten his constitutionally guaranteed right to a fair trial but, in addition, would also be prejudicial to the administration of justice in general. ${ }^{15}$

Although not largely elucidated upon in the opposition, Pistorius' Counsel did also argue that witnesses, especially defence witnesses, might be reluctant to testify on camera, thus further jeopardising their client's right to a fair trial. The author submits that it is indeed reasonably foreseeable that witnesses might, in order to assist an accused, be prepared to offer private or unpleasant revelations to a limited number of people physically present in a courtroom (the historical and traditional situation when a trial is held in an open court ${ }^{16}$ but may be very reluctant or even refuse to do so when they know those same revelations will become common knowledge of the greater public because their testimony, image and/or voice are being broadcast to millions. ${ }^{17}$

Interestingly, a South African court had already refused the televising of a judicial hearing for very similar reasons, inter alia, in the Midi Television (Pty) Ltd v Downer ${ }^{18}$ case, where E-TV brought an application to televise the trial proceedings in the matter of $S v$ Shaik. ${ }^{19}$ This was a very controversial and highly publicised case involving charges of fraud and

$14 \quad$ Application case para 12.

15 A fair trial is one component of the "rule of law" (Latin Omnes legum servi sumus ut liberi esse possumus) and the right to a fair trial has been espoused in legal literature and case law for centuries. Examples are, AEthelred Wantage Code 997 AD; Magna Carta 1297 c 9; Constitutions of Clarendon 1166; Constitution of the United States of America; Declaration of the Rights of Man and of the Citizen, 1789 (Fr); Re Bushell 1670124 ER 1006; Blackstone Laws of England; Universal Declaration of Human Rights (1948); European Convention on Human Rights (1950); Melikan Trial in History Vol II; Mulholland and Pullan Trial in History Vol I; Petition of Right, 1628. DOFORSA Rule of Law 47: "The rule of law ... general agreement that it requires that a person on trial be accused in open court; be given an opportunity of denying the charge and of defending himself and that he be given the choice of a Counsel. These rights are at all times assured by the South African Courts." Also see Criminal Procedure Act 51 of 1977 s 152 "Except where otherwise expressly provided by this Act or any other law, criminal proceedings in any court shall take place in open court..."

17 Counsel's concerns did apparently come to fruition. Anonymous 2014 http://www.bbc.com/news/world-africa-28207346: "Some [defence] witnesses refused to testify at the televised trial of Oscar Pistorius because of the publicity ... They did not want their voices all over the world" Barry Roux SC was quoted as saying at the close of the defence case.

18 Midi Television (Pty) Ltd v Downer 2004 ZAKZHC 15 (12 October 2004).

$19 S$ S Shaik 20071 SACR 142 (D). 
corruption against a wealthy Durban businessman, Mr Shabir Shaik, whose name was closely associated in the public's mind with that of a then former Deputy President and now the current President of South Africa, Mr Jacob Zuma. In considering the matter Squires $\mathrm{J}$ took pains to analyse all pertinent factors and in eventually refusing to grant the application to televise the trial stated:20

The video camera may be the necessary tool of the television journalist but its visible presence, in this courtroom at any rate, would be undoubtedly a visible operation, with both its presence and its operation being conspicuously intrusive. To most people it would be a potentially distracting feature, even if they were not giving evidence. But I think the argument also overlooks an important difference between the fleeting moment of communication by word of mouth, given only as part of the normal narrative of evidence and given in answer to a question when, if spectators may be paying attention, what is said may be reported in print the next day but will soon be forgotten. Contrast that with a permanently-captured moment of inadvertent folly, embarrassment or humiliation that will appear time after time, if thought desirable, in the living rooms of the country's television watchers when every pause, every frown, every hesitation, every unguarded response or unavoidable disclosure of some private fact is preserved on tape or film for as long as thought desirable, and especially when that frown or hesitation is not part of the evidence or the reason for it; but is caused by the witness's realisation that he is being exposed to television scrutiny. No one but the witness could tell what the cause was. Nor would he waive or limit his right to privacy by being subpoenaed to give evidence in court.

An issue aligned to the above concern of Squires $\mathrm{J}$ is that the fairness of a trial may also be jeopardised as a result of changes in human behaviour when they are aware that what they say or do is being heard or viewed by a large audience, even if such changes are unintended or even inadvertent. It has been advanced that witnesses may, when participating in a broadcast trial, especially one that is visually broadcast, fall prey to the temptation to embellish or distort their true testimony in order to appeal to or find favour with the audience. ${ }^{21}$ Doing so is obviously at the expense of the fulfilment of their moral and judicial obligation to "tell the truth, the whole truth and nothing but the truth so help me God". ${ }^{22}$

\section{Judgment}

At the outset of his consideration of the arguments presented the Judge President regarded the matter before him as being one where the media's

\footnotetext{
$20 \quad$ Midi Television (Pty) Ltd v Downer 2004 ZAKZHC 15 (12 October 2004) paras 8-9.

21 Smith 1997 Law \& Psychol Rev 258.

22 The traditional oath sworn in court and used to designate the absolute veracity of any statement subsequently made, see s 162 of the Criminal Procedure Act 51 of 1977.
} 
right to freedom of expression and the defendant's and the prosecution's right to a fair trial were "on a collision course" with each other. ${ }^{23}$ Given the context of the motion it is not apparent how the court arrived at the conclusion that the prosecution (in the form of the State) had a "right to a fair trial". Try as the author may, she can find no such embodied right belonging to the State, either in the Constitution, its forerunners or in legal precedent. That the prosecution does indeed have an obligation to facilitate a criminal trial that searches for the truth is beyond question, but whether that means that the State is entitled to a "fair trial" (as that term is commonly understood by the layman) is a question better argued as a separate matter.

What is pertinent for this current contribution's purpose is the reason or reasons why the court foresaw a cataclysmic "collision course" for Pistorius and the media, especially given that South Africa's courts had touched upon similar issues previously. One of the first constitutional challenges to the refusal of public and media access to legal proceedings occurred, not in a commonly envisaged criminal trial per se, but in a military Court Martial. ${ }^{24}$ In deciding the matter of Freedom of Expression Institute $v$ President, Ordinary Court Martia ${ }^{5}$ Hlophe ADJP held that section 78(3) of the Military Discipline Code $^{26}$ was unconstitutional to the extent that "it permits a convening authority to issue orders to close proceedings". ${ }^{27}$ Hlophe then ordered the President, Ordinary Court Martial to:

Open the entire proceedings of the ordinary courts martial to the public including members of the media. ${ }^{28}$

Application case para 1. "The matter brings into sharp focus the interface between the functioning of the criminal justice system on the one hand, and the quest by other media and the press to participate in that system on the other hand. This interface finds expression in a number of critical constitutional rights that are seemingly on a collision course with one another. These are the rights of an accused person and the prosecution to a fair trial on the one hand, and the freedom of expression rights of the media, as well as the open justice principle." A court-martial is a military court with legal authority to determine the guilt or innocence of members of the armed forces subject to military law, and, if guilty to decide punishment. Freedom of Expression Inst v President, Ordinary Court Martial 19991 SACR 353 (C).

The Military Discipline Code (MDC) is the First Schedule to the Defence Act 44 of 1957. It is to be read complementarily to the Military Discipline Supplementary Measures Act 16 of 1999. Freedom of Expression Inst v President, Ordinary Court Martial 19991 SACR 353 (C) para 369.

28 Freedom of Expression Inst v President, Ordinary Court Martial 19991 SACR 353 (C) para 369. It is submitted that this ruling contradicts the long-established practice of all courts-martial and may have been a slightly over-enthusiastic approach to interpreting South Africa's constitutional rights. Military law and procedure has 
In 2000 a Cape court was faced with another challenge concerning media access to legal proceedings that did not constitute a criminal trial. This time it concerned the radio broadcasting and televising of an enquiry into cricket match fixing - the case of Dotcom Trading 121 (Pty) Ltd $v$ King. ${ }^{29}$ The enquiry's Chairperson had refused permission for the coverage, a ruling the majority of the potential witnesses had enthusiastically welcomed. After considering all the relevant factors the court held that a complete blanket ban on all forms of the media from the enquiry was not justified. ${ }^{30}$ Consequently, the court held that the applicant could operate its radio broadcasting equipment during the enquiry proceedings, provided that no witness showed good cause why they should not do so. ${ }^{31}$ The order banning any televised recording or broadcasting of the enquiry was, nevertheless, promptly upheld. ${ }^{32}$

A request to televise and broadcast actual trial proceedings (albeit a civil trial and not a criminal one) eventually came before a Cape court in $S A B C$ $v$ Thatcher. ${ }^{33}$ After Van Zyl J conducted an extremely comprehensive and detailed analysis of local and international authority on the issue, which included inter alia authority in the United States, Canada and the United Kingdom, ${ }^{34}$ he granted very restricted coverage. In conducting his analysis the judge stated that: 35

In South Africa there is no legislative ban on televising or otherwise recording court proceedings, but a number of courts have, by virtue of their inherent power to regulate their own procedures, allowed their proceedings to be televised wholly or partially. This has been done routinely in the Constitutional Court and Supreme Court of Appeal, and has recently enjoyed the attention of a number of divisions of the High Court. Cognisance must, of course, be taken of the statutory provisions dealt with above, in which regard it is clear that the applicant bears the responsibility of acting in the public interest, while taking into account the interests of justice. The court, on the other hand, must exercise its discretion to issue a just and equitable order while taking cognisance of its inherent power to regulate its own proceedings. This means, in the present context, that the right of privacy of the various parties to the application must be weighed up and balanced against the right of freedom of expression which, in the case of the media, translates into freedom of the press. An exercise of this nature must be undertaken with due regard to any

always been treated differently in jurisdictions based on English common-law. Also see Jaconelli Open Justice 22-24; Ex p Doyle 19172 KB 254.

Dotcom Trading 121 (Pty) Ltd v King 20004 SA 973 (C).

Dotcom Trading 121 (Pty) Ltd v King 20004 SA 973 (C) para 61 991D-H.

Dotcom Trading 121 (Pty) Ltd v King 20004 SA 973 (C) para 63 991I-992A.

Dotcom Trading 121 (Pty) Ltd v King 20004 SA 973 (C) para 63 991I-992A.

$S A B C v$ Thatcher 20054 All SA 353 (C).

$S A B C v$ Thatcher 20054 All SA 353 (C) paras 51-109 both inclusive.

$S A B C \vee$ Thatcher 20054 All SA 353 (C) para 31. 
reasonable or justifiable limitation on the right or rights in question, as stated in the classic dictum of Chaskalson P in S v Makwanyane: ${ }^{36}$

The limitation of constitutional rights for a purpose that is reasonable and necessary in a democratic society involves the weighing up of competing values, and ultimately an assessment based on proportionality. ${ }^{37}$

The court considered the need to balance the right to privacy against the right to freedom of expression (which from the perspective of the press meant its freedom) and held that in all instances, the balance must be based on fairness and reasonableness. ${ }^{38}$ The author submits that Van Zyl J's full analysis is an excellent exposé of upholding the rationale of open justice, whilst simultaneously placing both the general public's and the media's interests into a correct relationship with that of a presumptively innocent accused.

Two years later, in 2007, when hearing Midi Television Pty Ltd v Director of Public Prosecutions (WC), ${ }^{39}$ the Supreme Court of Appeal gave additional guidance on the approach a court should consider when called upon to balance opposing constitutional rights in matters concerning the broadcasting of court proceedings and held that competing rights: ${ }^{40}$

... cannot be reconciled by purporting to weigh the value of one right against the value of the other and then preferring the right that is considered to be more valued. They are rather to be reconciled by recognising a limitation upon the exercise of one right to the extent that it is necessary to do so in order to accommodate the exercise of the other ... according to what is required by the particular circumstances and within the constraints that are imposed by s36.

The Supreme Court of Appeal had also had an opportunity to deal with a matter that contained almost identical arguments to those facing the Judge President in the Oscar matter, although the Supreme Court of Appeal had been considering a criminal appeal hearing and not a criminal trial per se. In $S A B C v$ Downer and Shaik $k^{41}$ the South African Broadcasting Company, as the national public broadcaster, ${ }^{42}$ applied to televise and sound-record a specific appeal hearing which it claimed possessed considerable public

\footnotetext{
$36 \quad$ S v Makwanyane 19953 SA 391 (CC).

$37 \quad S$ v Makwanyane 19953 SA 391 (CC) para 104 436C.

$38 \quad S A B C v$ Thatcher 20054 All SA 353 (C) para 123.

$39 \quad$ Midi Television Pty Ltd v Director of Public Prosecutions (WC) 20075 SA 540 SCA.

$40 \quad$ Midi Television Pty Ltd v Director of Public Prosecutions (WC) 20075 SA 540 SCA para 549.

$41 \quad$ SABC v Downer and Shaik 20071 All SA 384 (SCA).

$42 \quad$ Broadcasting Act 4 of 1999.
} 
interest. ${ }^{43}$ The SABC argued that, in addition to supplying content for its news programmes, the televising of the appeal hearing would educate the general public about how South Africa's judiciary worked. ${ }^{44}$ The respondents in their opposition argued that the awareness of the live televising would not only continually distract their Counsel, but also risked disrupting the required expansive forensic presentation. ${ }^{45}$ They further contended that both these factors would cause prejudice and thus would inevitably threaten the provision of a fair hearing. ${ }^{46}$

In deciding the matter, the Supreme Court of Appeal held that there was no general rule to balance the right to freedom of expression against the right to a fair trial, and in the event that any such balancing should actually be required, it would be unique to the peculiarities of each case under consideration. ${ }^{47}$

Notwithstanding that the Supreme Court of Appeal readily agreed with the argument that for a litigant to be on camera does carry substantial stress which magnifies exponentially as the trial continues, ${ }^{48}$ it did still nevertheless hold that there could be certain specific instances when an individual court would be satisfied that justice would not be impaired. The current matter before the Supreme Court of Appeal was not, however, such an occasion. ${ }^{49}$

When it was asked to consider if perhaps parts of the appeal hearing in question could be televised, the Supreme Court of Appeal pointed out that:

It needs to be emphasised that delayed 'highlights' packages, which will most times contain 'sound bites', present a considerable risk of misrepresentation (even if unintended) and consequent misunderstanding. ${ }^{50}$

When it came to the SABC's claim that the televising of the hearing would educate the public, the Supreme Court of Appeal unsurprisingly, but nevertheless astutely, held that although educating the public on South Africa's judicial system was indeed overdue:

\footnotetext{
43 The appeal concerned Shabir Schaik's conviction on corruption and fraud charges.

$44 \quad$ SABC v Downer and Shaik 20071 All SA 384 (SCA) para 7.

$45 \quad$ SABC $v$ Downer and Shaik 20071 All SA 384 (SCA) para 8.

$46 \quad$ SABC v Downer and Shaik 20071 All SA 384 (SCA) para 8.

$47 \quad$ SABC v Downer and Shaik 20071 All SA 384 (SCA) para 14.

$48 \quad$ SABC v Downer and Shaik 20071 All SA 384 (SCA) para 22.

$49 \quad$ SABC v Downer and Shaik 20071 All SA 384 (SCA) para 30.

$50 \quad$ SABC v Downer and Shaik 20071 All SA 384 (SCA) para 29.
} 
...the motive [for the application] was in my view the perfectly understandable one of securing the commercial advantage of enhanced viewer- and listenership. ${ }^{51}$

Not satisfied with the resultant negative ruling against them, the applicants speedily appealed to the Constitutional Court. $^{52}$ They were to be disappointed. The Constitutional Court, in a majority ruling, agreed with the views of the Supreme Court of Appeal and pointed out the following aspects for courts to consider if and when they were faced with similar applications for the televising of judicial proceedings in the future:

We consider it helpful to set out some considerations which in our view need to be taken into account in the future when the question of televising court proceedings is raised. The time has come for courts to embrace the principle of open justice and all it implies. However, in our view, it should be borne in mind that the electronic media create some special difficulties for the principle of open justice. Broadcasting, whether by television or radio, has the potential to distort the character of the proceedings. This can happen in two ways: first, by the intense impact that television, in particular, has on the viewer in comparison to the print media; and second, the potential for the editing of court proceedings to convey an inaccurate reflection of what actually happened. This is particularly dangerous given that visual and audio recordings can be edited in a manner that does not disclose the fact of editing. This distorting effect needs to be guarded against. It arises not so much from the presence of cameras and microphones interfering with the court proceedings themselves, but more dangerously, it may arise from the manner in which coverage can be manipulated, often unwittingly, to produce communications which may undermine rather than support public education on the workings of the court and may also undermine the fairness of the trial..$^{53}$

Although the Constitutional Court was referring to appeal hearings in the above quotation, the court did nevertheless very importantly take the opportunity to state that:

Ordinarily, it will not be in the interests of justice for trial proceedings to be subjected to live broadcasts. (Emphasis added). ${ }^{54}$

Given these judicial rulings and guidelines by the superior courts it is therefore unclear why the rights of the media and those of Pistorius were regarded by the Judge President as being on an imminent collision course. ${ }^{55}$

This anticipated cataclysmic event notwithstanding, the Judge President proceeded to consider the applicant's claim that as Pistorius was an "international icon", the upcoming criminal trial was a matter of intense

SABC v Downer and Shaik 20071 All SA 384 (SCA) para 30.

$S A B C \vee$ National Director of Public Prosecutions 20071 SA 523 (CC).

$S A B C$ v National Director of Public Prosecutions 20071 SA 523 (CC) para 68.

$S A B C$ v National Director of Public Prosecutions 20071 SA 523 (CC) para 33.

Application case para 1. 
public interest. ${ }^{56}$ In support of this finding, the court explained that the depth of the interest had already been clearly illustrated by the:

...near chaotic situation that was experienced in the Magistrates Court of this city [Pretoria], when Pistorius applied for bail last year. It is common cause that during those proceedings the courtroom allocated for the bail proceedings was wholly inadequate and could not accommodate all the journalists and members of the public who showed up seeking to attend and cover the proceedings. It is also common cause that the media attention and coverage of the bail proceedings attracted journalists far beyond our borders. Those proceedings were in fact extensively covered by the print, broadcast and electronic media locally and internationally. The interest in the upcoming trial has remained very strong with international media houses sending scores of journalists to cover it. This background is relied on as a basis by the applicants to assert that it is in the public interest that they be granted permission to cover the trial with a view to informing all and sundry about it. ${ }^{57}$

Continuing the topic of the pending trial's being a matter of intense public interest, the court proceeded to hold:

I have come to decide to ensure that a greater number of persons in the community who have an interest in the matter but who are unable to attend these proceedings due to geographical constrains to name just one, are able to follow the proceedings wherever they may be. Moreover, in a country like ours where democracy is still somewhat young and the perceptions that continue to persist in the larger section of South African society, particularly those who are poor and who have found it difficult to access the justice system, that they should have a first-hand account of the proceedings involving a local and international icon. ${ }^{58}$

The author respectfully submits that in the above rulings the court misdirected itself in its definition of what constitutes the public interest in the administration of justice. Instead the court concentrated erroneously on factors that either appealed to individual members of the public, that certain members of the public may have been curious about, or that certain individual members of the public may have had a personal or even a morbid interest in - none of which constitutes the true public interest in the administration of justice.

In support of her argument the author argues firstly that the court initially considered what was convenient for the public, namely any geographical constraints on members of the public to get to the court itself. She argues that the physical location of the members of the public, which may prove to cause an inconvenience for certain people if they voluntarily desire to go to a court, is not representative of the true public interest in the administration 
of justice. Secondly, the court held that it is appropriate for people who have never previously interacted with the justice system themselves to acquire a "first-hand" account of how the system deals with a "local and international icon". ${ }^{59}$ The author submits that again this ruling is not representative of the true public interest in the administration of justice. The fact that certain individual members of the public may find the trial events personally interesting, or that they may be entertained by watching the trial is irrelevant when speaking of the true public interest in the administration of justice.

On a slightly different note but one the author considers to be of the utmost importance, although Oscar Pistorius is internationally famous for his sporting achievements and overcoming his severe physical disability (personal triumphs which presumably justified the "icon" accolade awarded by the court) these achievements do not, did not, and could not, place any onus on him whatsoever to educate the general public on how South Africa's criminal system works. What is fundamental and should not be forgotten by all concerned is that as a presumptively innocent accused, Oscar Pistorius owed the public absolutely nothing in this matter.

The court then enigmatically proceeded to take judicial notice of a perception, viz:

I have taken judicial notice of the fact that part of the perception that I allude to is the fact that the justice system is still perceived as treating the rich and famous with kid gloves whilst being harsh on the poor and vulnerable. Enabling a larger South African society to follow first-hand the criminal proceedings which involve a celebrity, so to speak, will go a long way into dispelling these negative and unfounded perceptions about the justice system, and will inform and educate society regarding the conduct of criminal proceedings. ${ }^{60}$

The court's taking judicial recognition of an intangible perception, let alone one that the rich and famous are treated "with kid gloves" whilst the poor and vulnerable are treated "harshly", is surprising if not ground-breaking to say the least. It is noteworthy that there was a dearth of authority or even a submission of a basis upon which the quoted perception qualified for, or even warranted, judicial recognition. Having effected such an abnormal judicial recognition, however, the court itself proposed a partial solution to the problem of how to eradicate or correct this apparent, negative perception. The court reasoned that this (now judicially recognised) perception would be largely negated if a substantial portion of the public

\footnotetext{
$59 \quad$ Application case para 27.

$60 \quad$ Application case para 27.
} 
was able to view "first-hand" how the system conducts criminal proceedings against a celebrity. ${ }^{61}$

The author argues that it is not the responsibility of any individual member of the public and least of all the responsibility of a presumptively innocent accused to correct public perceptions, especially a perception that has not been substantiated. Furthermore, and this is important, it is necessary to note that the fact that Pistorius is famous, rich and an icon (sporting or otherwise) should have been totally irrelevant and of absolutely no consequence whatsoever to the court in its consideration of the matter before it. The Constitution itself prescriptively mandates that a court must apply the law "impartially and without fear, favour or prejudice". ${ }^{62}$

In then considering the applicant's argument that it possessed the constitutional right to freedom of expression, the court referred to the value afforded to this freedom in legal precedent and quoted from the Constitutional Court ruling in Khumalo $v$ Holomisa ${ }^{63}$ that had stressed the following with regard to the role played by the media:

The print, broadcast and electronic media have a particular role in the protection of freedom of expression in our society. Every citizen has the right to freedom of the press and the media and the right to receive information and ideas. The media are key agents in ensuring that these aspects of the right to freedom of information are respected. ${ }^{64}$

The court then went on to quote from another judgment of the Constitutional Court viz South African National Defence Union v Minister of Defence ${ }^{65}$ to wit:

\begin{abstract}
Freedom of expression lies at the heart of a democracy. It is valuable for many reasons, including its instrumental function as a guarantor of democracy, its implicit recognition and protection of the moral agency of individuals in our society and its facilitation of the search for truth by individuals and society generally. The Constitution recognises that individuals in our society need to be able to hear, form and express opinions and views freely on a wide range of matters. 66
\end{abstract}

There can be no argument with the sentiments quoted above as a generalisation of the media's role, nor can there be any argument with the Judge President's subsequent referral to the previously discussed

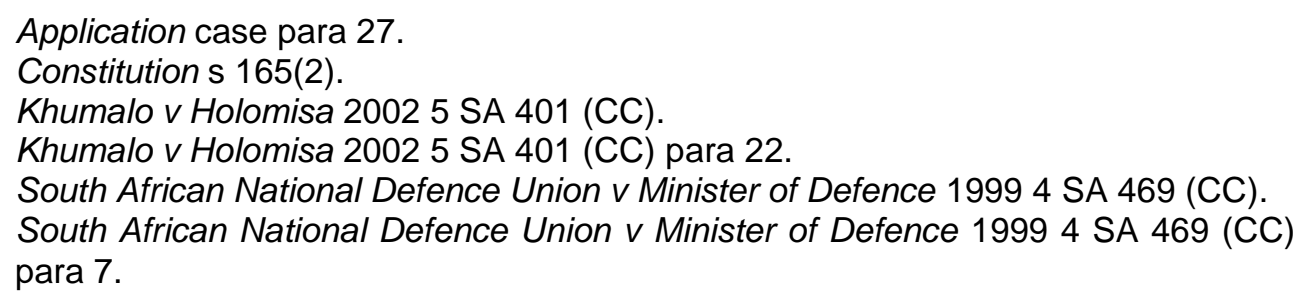


Constitutional Court matter of SABC v National Director of Public Prosecutions. ${ }^{67}$ What can be strenuously argued against, however, is that the Judge President did not quote, or even acknowledge, what was undoubtedly the most important and the most relevant part of that latter Constitutional Court ruling, embodied in paragraph 33 as follows:

Ordinarily, it will not be in the interests of justice for trial proceedings to be subjected to live broadcasts. (Emphasis added).

Why the Judge President failed to acknowledge this most relevant statement of the Constitutional Court and then consider it in the matter before him is unknown and worrying.

The author also submits that in its consideration of the Application case the court erred (no doubt inadvertently) by taking a legal finding and applying it to a different contextual matter. The Khumalo $v$ Holomisa case concerned defamation and the quotation that the Judge President referred to was made when the Constitutional Court was denoting the openness of government and the media's role in providing information to enable the public to be in a position to make political decisions. The Constitutional Court was not talking of the media's possible role in the televising of a criminal trial. ${ }^{68}$

Similarly, when the Judge President made reference to the South African National Defence Union v Minister of Defence case, the context of the original quotation was in that of:

\section{... the question whether it is constitutional to prohibit members of the armed forces from participating in public protest action and from joining trade unions. ${ }^{69}$}

More pertinently, when O'Reagan $\mathrm{J}$ made the statement that the court relied upon, she was referring more explicitly to a soldier's right to indulge in protest action, thus allowing him (as an individual) the right to freedom of expression. ${ }^{70}$ This context is again a far cry from the consideration of the media's right to live televise a full criminal trial.

In continuing his decision on the application before him, the Judge President confirmed that he personally regarded press reports of trial proceedings as

$67 \quad S A B C$ v National Director of Public Prosecutions 20071 SA 523 (CC).

$68 \quad$ Khumalo v Holomisa 20025 SA 401 (CC) para 22.

69 South African National Defence Union v Minister of Defence 19994 SA 469 (CC) para 1.

70 South African National Defence Union v Minister of Defence 19994 SA 469 (CC) para 7. 
being "second-hand", and held that if Pistorius' objections to televising and/or audio broadcasting of his trial were upheld,

... it will perpetuate the situation that only a small segment of the community is able to be kept informed about what happens in court rooms because of this minority's access to tools such as Twitter. ${ }^{71}$

The author submits that in addition to the relevance of these comments being unclear, the issue whether the court itself views newspaper reports as "second-hand" and/or how few people use Twitter had doubtful applicability in the matter. If, however, the court intended to reference socioeconomic issues, then the author argues that a presumptively innocent accused has no duty to correct or to alleviate such socio-economic issues, nor does an accused bear any obligation to be used as an unwilling mechanism in addressing such issues. The author similarly has difficulty in understanding why the court would regard newspaper reports as "secondhand", yet brief text messages emanating from media persons via Twitter as not "second-hand".

The court continued its findings by dramatically stating that if Pistorius' opposition to the application to widely broadcast/televise his coming trial was allowed to prevail, the media's entitlement to freedom of expression would be "attenuated" and the principle of open justice would "suffer the same fate". ${ }^{72}$ The court consequently held that Pistorius' objections to his trial being photographed and broadcast was contrary to the "open justice" principle ${ }^{73}$ and supported its view with reference to the Constitutional Court matter of $S \vee$ Mamabolo, ${ }^{74}$

... the business of adjudication concerns not only the immediate litigants but is a matter of public concern which, for its credibility, is done in the open where all can see. Of course this openness seeks to ensure that the citizenry know what is happening, such knowledge in turn being a means towards the next objective: so that the people can discuss, endorse, criticize, applaud or castigate the conduct of their courts. And, ultimately, such free and frank debate about judicial proceedings serves more than one vital public purpose. Self-evidently such informed and vocal public scrutiny promotes impartiality, accessibility and effectiveness, three of the important attributes prescribed for the judiciary by the Constitution. ${ }^{75}$

This is a further unfortunate example of the Judge President's taking a quotation out of context. The Mamabolo matter concerned a charge of

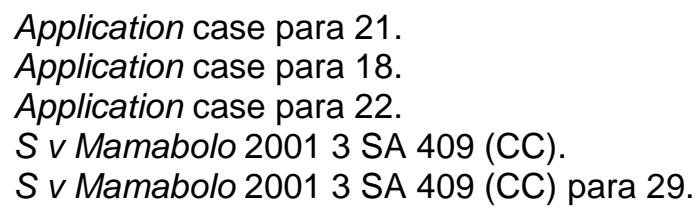


contempt of court and when making the above statement Kriegler $\mathrm{J}$ was referring to the difference between the criticisms of an individual judicial officer versus criticism of the judiciary - again nothing to do with the televising of a criminal trial by the media. Nevertheless, the author agrees that the above quotation from Mamabolo does indeed assist in correctly explaining the premise of the "open justice" principle. The author suggests, however, that what the court hearing the Pistorius application appears not to have considered is that the holding of criminal trials is but one element and component of an "open justice" system. She submits that in the application before it, the court appeared to have taken the holistic principle of "open justice" and applied it, in its most expansive sense and unfortunately erroneously, to one single criminal trial of a solitary citizen.

The author also makes the point that at no time had Pistorius sought to exclude the public from his trial courtroom, nor had he ever argued against the press' historical right to attend a trial to compile textual newspaper reports - both of which align with legal proceedings being open to view and thus accord with the principle of open justice. It therefore follows that Pistorius had never, at any time, attempted to "attenuate" the freedom of the press, nor had he ever made any attempt to endanger the open justice principle, both of which is precisely what the court held Pistorius did do. The author posits that the court appeared to have lost sight of the fact that Pistorius' objections to the application focussed on the following pertinent factors, namely that the press would be permitted to continuously take photographs during the on-going trial proceedings, the possibility that the live transmission of the trial would enable pending witnesses to hear/see already presented testimony and/or evidence thus providing them with the opportunity to manipulate their own testimony, and finally, that televising the trial to a world-wide audience would place an undue burden on the defence - all of which would jeopardise his constitutionally guaranteed right to a fair trial.

In its consideration of the right to a fair trial, the court had no hesitation in acknowledging that it was an important matter for consideration, ${ }^{76}$ but then promptly held that the right to a fair trial must be balanced against the right to freedom of expression. ${ }^{77}$ In balancing these rights the court held that:

$76 \quad$ Application case para 13.

$77 \quad$ Application case para 11. 
... its point of departure was to ensure that each of the rights asserted find proper expression and enjoyment without being unduly limited. ${ }^{78}$

To facilitate this intention the court believed that its task entailed that it must:

... look at each right at stake and permit its enjoyment to achieve the objective for which it is asserted. ${ }^{79}$

Seeming to have already decided the matter, the court found that "court proceedings are in fact public and this objective must be recognised". ${ }^{80}$ In addition, and of major significance, the court also held that the

Constitution's sections 34 and 35(3)(c) make it very clear that even criminal proceedings in this country are to be public. ${ }^{81}$

The writer again respectfully submits that in this latter portion of its ruling the court very significantly misdirected itself, possibly even being instrumental in leading to a flawed ruling. The sections of the Constitution that the court referred to contain no such stipulation, nor are they even peremptory. Section 35(3)(c) in particular does not mandate that an accused must undergo a "public trial", but just simply states that an accused person has the exclusive right to have one. ${ }^{82}$

\section{Conclusion}

In closing, the author submits that when deciding the application to televise the Oscar Pistorius trial the court occasionally, and unfortunately very significantly, misdirected itself in its considerations and subsequent rulings on the constitutional rights of the parties concerned. It is also unfortunate that the arguments presented to the court were solely limited to the respective parties' constitutional entitlements, thus technically restricting the scope of the court's judgment. It is emphasised, however, that matters were complicated for the court not only by the overwhelming world media attention on the coming trial, making it unique in South Africa's jurisprudence and the first of its intense nature to occur under the Constitution, but also by the fact that the trial itself was imminent.

\footnotetext{
$78 \quad$ Application case para 19.

$79 \quad$ Application case para 19.

$80 \quad$ Application case para 22.

$81 \quad$ Application case para 23.

82 See James Open Court for the distinction between what constitutes a "public trial" versus what constitutes a criminal trial being held in an "open court", which is South Africa's common-law position and is also the legislated procedure in the Criminal Procedure Act 51 of 1997 s 152.
} 
The author speculates that had the arguments presented to the court been expanded to include the open court versus public trial conundrum, ${ }^{83}$ had the significant misdirections been absent and/or had the court been afforded more time for consideration, the resultant judgment may have differed appreciably. Regrettably, the court was not afforded these opportunities and the application for the television, audio and photographic coverage of the trial was granted, albeit subject to detailed conditions. The rest, as they say, is history.

What is interesting is that shortly after the trial of Oscar Pistorius another proverbial high-profile criminal trial was due to get underway in South Africa - that of Shrien Dewani. Dewani was accused of being complicit in the murder of his new bride while they were on honeymoon in Cape Town. Dewani left for the United Kingdom shortly after his wife's murder and lengthy protracted extradition processes were undertaken to ensure he returned to South Africa to stand trial. The pending trial aroused considerable world-wide interest and it was highly anticipated that following the televising of the Pistorius trial, Dewani's trial would provide a suitable sequel. Despite the anticipation, however, Dewani's trial was not broadcast.

As at the time of finalisation of this article, the trial of accused family murderer Henri van Breda is on-going in the Western Cape High Court. Although permission to broadcast the trial had been initially granted by Judge Siraj Desai, ${ }^{84}$ a subsequent appeal by both the defence and the National Prosecuting Authority has halted the live broadcast.

It thus remains to be seen whether the televising or other live broadcasting of criminal trials becomes an accepted part of South Africa's criminal procedure.

\section{Bibliography}

\section{Literature}

Blackstone Laws of England

Blackstone W Commentaries on the Laws of England 1765-1769 (Clarendon Press Oxford 1770)

83 See James Open Court for the distinction between a "public trial" and one held in an "open court".

$84 \quad$ Media 24 Limited $v$ National Director of Public Prosecutions, In re S $v$ Van Breda 2017 ZAWCHC 36 (27 March 2017). 
DOFORSA Rule of Law

Department of Foreign Affairs of the Republic of South Africa South Africa and the Rule of Law (Government Printers Pretoria 1968)

Jaconelli Open Justice

Jaconelli J Open Justice: A Critique of the Public Trial (Oxford University

Press Oxford 2002)

James Open Court

James AAW Open Court Versus Public Trial: An Analysis of the Constitutional Distinction in South African Criminal Procedure (LLMdissertation University of South Africa 2016)

Melikan Trial in History Vol II

Melikan RA Trial in History, Volume II - Domestic and International Trials, 1700-2000 (Manchester University Press Manchester 2003)

Mulholland and Pullan Trial in History Vol I

Mulholland MM and Pullan B Trial in History, Volume I - Judicial Tribunals in England and Europe, 1200-1700 (Manchester University Press Manchester 2003)

Smith 1997 Law \& Psychol Rev

Smith T "The Distortion of Criminal Trials through Televised Proceedings" 1997 Law \& Psychol Rev 258-269

\section{Case law}

Dotcom Trading 121 (Pty) Ltd v King 20004 SA 973 (C)

Exp Doyle 19172 KB 254

Freedom of Expression Inst $v$ President, Ordinary Court Martial 19991 SACR $353(\mathrm{C})$

Khumalo v Holomisa 20025 SA 401 (CC)

Media 24 Limited v National Director of Public Prosecutions, In re $S v$ Van Breda 2017 ZAWCHC 36 (27 March 2017)

Midi Television Pty Ltd v Director of Public Prosecutions (WC) 20075 SA 540 (SCA) 
Midi Television (Pty) Ltd v Downer 2004 ZAKZHC 15 (12 October 2004)

Multichoice (Pty) Ltd v National Prosecuting Authority, In Re; S v Pistorius, In Re; Media 24 Ltd v Director of Public Prosecutions North Gauteng 2014 1 SACR 589 (GP)

Re Bushell 1670124 ER 1006

S v Makwanyane 19953 SA 391 (CC)

S v Mamabolo 20013 SA 409 (CC)

S v Pistorius 2014 ZAGPPHC 793 (12 September 2014)

$S$ v Shaik 20071 SACR 142 (D)

SABC v Downer and Shaik 20071 All SA 384 (SCA)

SABC v National Director of Public Prosecutions 20071 SA 523 (CC)

SABC v Thatcher 20054 All SA 353 (C)

South African National Defence Union v Minister of Defence 19994 SA 469 (CC)

\section{Legislation}

Broadcasting Act 4 of 1999

Constitution of the Republic of South Africa, 1996

Criminal Law Amendment Act 105 of 1997

Criminal Procedure Act 51 of 1977

Defence Act 44 of 1957

Military Discipline Code (MDC) - First Schedule to the Defence Act 44 of 1957

Military Discipline Supplementary Measures Act 16 of 1999 
International instruments

AEthelred Wantage Code 997 AD

Constitutions of Clarendon 1166

Constitution of the United States of America

Declaration of the Rights of Man and of the Citizen, 1789 (Fr)

European Convention on Human Rights (1950)

Magna Carta 1297 c 9

Petition of Right, 1628

Universal Declaration of Human Rights (1948)

Internet sources

Anonymous 2014 http://www.bbc.com/news/world-africa-28207346

Anonymous 2014 Oscar Pistorius Trial: Some Witnesses Refused to Testify http://www.bbc.com/news/world-africa-28207346 accessed 14 March 2015

Stats SA $2011 \quad$ http://www.statssa.gov.za/publications/P03014/ P030142011.pdfStatistics South Africa 2011 Census http://www.statssa.gov.za/publications/P03014/P030142011.pdf accessed 18 May 2015

\section{List of Abbreviations}

DOFORSA

Law \& Psychol Rev
Department of Foreign Affairs of the Republic of South Africa Law and Psychology Review 